\title{
ANALYSEN UND BERICHTE
}

\section{Fighting Transboundary Waste Streams: Will the Basel Con- vention help?}

\author{
By Susanne Rublack
}

\section{Introduction}

The Basel Convention on the Control of Transboundary Movements of Hazardous Wastes and their Disposal, finalized after seventeen months of negotiations 1 , was adopted in the course of a rather heated diplomatic conference on 22 March 1989. It is the first global instrument subjecting the increasing transboundary flow of hazardous materials to restrictions. In summary, the core of the regulatory body 2 consists of a modified ban of hazardous waste trade with states non-parties to the convention and a procedure mandating that waste importing states and such states through whose territory the wastes will be transited obtain notification on a projected movement and must consent in writing 3 prior to its initiation. Ecological standards have been introduced only in vague shape; they require further elaboration. A provision on illegal traffic allocates responsibilities to ensure environmentally sound management of wastes which have been exported in contravention of the convention.

The drafting process for the convention took place under the auspices of the United Nations Environment Programme (UNEP) which, entrusted with the tasks of catalysing, co-ordinating and stimulating environmental action within the UN system, has in recent years deve-

1 The Final Act of the conference and the Basel Convention have been published in 28 I.L.M. 649 (1989). - The text of the convention itself is reprinted in the DOCUMENTATION section of this issue of Verfassung und Recht in Übersee. An unofficial German translation of the convention has been published in Stiftung Entwicklung und Frieden (Hrsg.), Die Umwelt bewahren, Bonn-Bad Godesberg 1989, pp. 143 - 172. - The organizational meeting of the working group which prepared a total of five drafts of the convention text took place in Budapest in October 1987.

2 The convention text contains several annexes on definitional questions, procedural and technical matters. It will be further supplemented by a protocol on liability and by guidelines on waste management practices.

3 Transit countries may opt for a Prior Informed Choice procedure allowing for the exporting country's approval of a waste movement, if no response has been received within 60 days, Art. 6 para. 4 of the convention. 
loped a strong focus on the promotion of international environmental law ${ }^{4}$. In 1984, UNEP convened a working group of experts with the mandate to elaborate a set of non-legally binding rules which would commit states to ensure the safe transport, handling and disposal of toxic and dangerous wastes5. The resulting Cairo Guidelines and Principles for the Environmentally Sound Management of Hazardous Wastes were intended to serve as model rules for national legislation and future bilateral, regional or global agreements 6 . For international trade in hazardous wastes, Guidelines 26 and 27 already introduce some shared responsibility of exporting and importing countries to ensure adequate protection of the environment and establish notification and consent requirements. With the adoption of the Cairo Guidelines by decision 14/30 of 17 June 19877, the UNEP Governing Council decided that another working group of legal and technical experts should prepare a global convention specifically on the aspects of transboundary waste movements. The following rounds of drafting and negotiations profited significantly from the work within the Organization for Economic Co-operation and Development (OECD) which was itself in the process of preparing a legally binding instrument on the subject.

To date, thirty-eight states have signed the Basel Convention 8 ; few of them belong to the major waste exporting or importing countries which have been involved in recent "dumping scandals". Twenty instruments of ratification or equivalent acts must be deposited with the United Nations Secretary-General until the treaty enters into force. So far, only Jordan's ratification has been received9.

Not contrary to observers' expectations, but with astounding vigour have the African states demonstrated that the present compromise on the control of international waste transfers is, from the perspective of the developing world, inadequate to present the final stage of a regulatory system with the ambition of global adherence. On behalf of the member countries of the Organization of African Unity (OAU), the minister of environment of Mali, Morifing Koné, announced to the delegates at Basel that the African countries were not prepared to sign the convention and that they would leave the formulation of a common

4 For a general presentation see UNEP, Environmental Law in the United Nations Environment Programme, Nairobi 1985. On the extension of environmental law activities, covering areas such as environmental impact assessment, biological diversity and climate change, see the 1988 Annual Report p. 71.

5 UNEP Goveming Council decision 10/24.

6 see the Report of the Ad Hoc Working Group of Experts on the Environmentally Sound Management of Hazardous Wastes at its First Session, UNEP/WG.95/5, p. 5.

7 Publicized as UNEP Environmental Law Guidelines and Principles No. 8, Nairobi 1987.

8 The West German government now also announced its decision to sign the Convention, Frankfurter Rundschau, 12 October 1989.

9 Information by the UNEP Secretariat as of 24 August 1989. 
position with respect to the adopted regime to a succeeding conference. The latter is expected to be convened in late 1989.

Despite frequent references to the "all in one boat" image, current attempts to develop a global approach towards pressing problems of environmental destruction all struggle with diverging positions of developing countries and the industrialized world: Still, twentyseven years after the Stockholm Conference on the Human Environment, claims of national sovereignty and of a right to compromise ecological necessities for the sake of economical stabilization and expansion are invoked to underline developing countries' reserved position on trade and production limits on substances which deplete the Ozone Layer ${ }^{10}$, or on common efforts to preserve tropical rain forests which are vital for the world climate and genetic diversity. In the context of transboundary trade in hazardous waste, the African countries' refusal to agree to the final compromise11 may again be understood as the expression of an unwillingness to share in the responsibility for burdensome consequences of the North's industrial pollution, which also accounts to a substantial part for the phenomena of climate change and depletion of the ozone layer12. Since the environmental pressure resulting from hazardous waste exports lies primarily on the developing countries, their own interest will be to work towards a jointly accepted, modified regime, if they continue to uphold their present rejecting position towards the adopted convention.

\section{Hazardous Waste Trade: Some Facts and Trends}

At the outset of international efforts to subject transfrontier waste movements to common rules and principles, the phenomenon seemed to be confined to the industrialized countries:

10 As an example, India has so far refused to ratify the 1987 Montreal Protocol on Substances that Deplete the Ozone Layer in consideration of the rising consumer potential in its own middle-class and of market opportunities within rapidly industrializing countries, see Neue Zürcher Zeitung No. 209, 10./11.9.1989.

11 However, 33 of the 40 African states represented at Basel have signed the Final Act of the Conference, thereby supporting several resolutions which call for signature of the convention, its harmonization with other international treaties and for support in the development of specific standards and rules to supplement the treaty provisions.

12 The global buildup of carbon dioxide, the most important contributor to the anthropogenetic greenhouse effect, is mainly caused by buming fossil fuels. Developing countries account for only 15 per cent of the world consumption of these energy sources; on the other hand, the deforestation of tropical rain forests results in the release of carbon dioxide which amounts to roughly one third of the release from buming fossil fuels. See the report of the World Commission on Environment and Development, Our Common Future, Oxford 1987, p. 169-177; UNEP 1987 State of the World Environment, p. 58-61; UNEP 1989 State of the World Environment, p. 20. 
In 1983 , when the occurrence of the Seveso affair ${ }^{13}$ prompted preparations within the Organization of Economic Co-operation and Development (OECD) for respective guidelines, an estimated 2.2 million tons of hazardous waste crossed the borders of the European member states of OECD for treatment, storage or disposal in another country14, approximately 1.5 million tons of which were destined for incineration or disposal at sea15. For all OECD countries, transfrontier movements involve about 10 per cent of the up to 300 million tons of annually produced hazardous wastes. Significant amounts of wastes from the Federal Republic of Germany, the Netherlands, Belgium and Denmark are sent to the German Democratic Republic for disposal16. The United Kingdom is another major waste receiving country for Western Europe, having increased its imports of hazardous wastes for treatment from 5,000 tons in 1981 to 53,000 tons in 1986/198717. It was not until 1988 that reports of hazardous waste shipments primarily to the Caribbean and to African countries called attention to the North-South dimension of international waste trade. A number of exports have also involved additional Eastern European countries, such as Romania, Hungary and Turkey18. The organization Greenpeace International, which has undertaken commendable efforts to document global trends and specific incidents of waste trade19, estimates that between 1986 and 1988, over 6 million tons of wastes have been exported from industrialized to developing countries and to Eastern Europe20. A recent overview of hazardous waste export agreements with African countries summarizes that of the 100 to 300 million tons annually produced in industrialized countries - roughly two thirds of them in the United States - , about 50 million tons were at least planned to be transferred to Africa21.

13 The 41 barrels of dioxinous wastes stemming from the 1976 Seveso industrial accident had been moved out of Italy in 1982 and finally, after eight months of search in several European countries, were rediscovered in France.

14 UNEP 1989 The State of the World Environment, p. 36 referring to the OECD 1985 State of the Environment Report.

15 Henri Smets, Transfrontier Movements of Hazardous Wastes, 14 Environmental Policy and Law 1985 , p. 16, 17.

16 Smets, ibd. p. 17.

17 UNEP 1989, The State of the World Environment, p. 36. Another source, citing a UK govemment official, speaks of the import of annually 24,500 tons for 1985 , having risen to 160,000 tons for 1987, see the report in International Environment Reporter 10 (1987), p. 536.

18 Examples may be found in a concise report of the United Nations Secretary-General on "Illegal traffic in toxic and dangerous products and wastes" which he presented to the Economic and Social Council at its second regular session of 1988 , following resolution $42 / 183$ of the United Nations General Assembly on the subject. See UN Doc. E/1988/72 of 16 May 1988.

19 In this article, the 5th German issue of the regularly updated Greenpeace documentation is used: Jim Vallette, Andreas Bernstorff, Der Intemationale Müllhandel: Eine Bestandsaufnahme von Greenpeace, March 1989.

20. Ibd., p. 9.

21 Roland Richter, Giftmüllexporte nach Afrika, Überblick, Zusammenhänge, Perspektiven, paper published by the Stiftung Wissenschaft und Politik (SWP - AP 2613), July 1989, p. 5. 
Estimates to quantify the production and transfrontier management of hazardous wastes face various difficulties which account for inaccurate and diverging data to be found in documentations on the subject: Above all, there has been no reliable or official monitoring of waste movements, and one of the rules of waste export business is obviously to observe greatest possible discretion, if not for the illegality of transactions then for fear of an awakening public opinion both in waste generating and in receiving countries. Under the Basel Convention, the parties will have to annually submit information inter alia on the amount of wastes exported and imported; however, discouraging experiences with the implementation of reporting duties following from other international agreements 22 give rise to doubts whether more comprehensive statistics will be available in the future.

In many of the recent incidents of waste exporting to developing countries, the exact amounts of wastes involved and the final status of an export project - whether implemented or cancelled - are subject to speculation. Finally, diverging national classifications of wastes as "toxic" or "hazardous", if existent at all, demand for caution in using comparative data on hazardous waste production and management. Nevertheless, certain developments pointing to a factual internationalization of waste management problems as well as to the need of their global control may be identified and illustrated by specific incidents which this was their positive effect - have highlighted the subject matter at a time when negotiations on the UNEP Draft Convention were in need of dynamic input.

The extending international waste trade is primarily caused by the incapability of industrialized countries to cope with the amounts of hazardous waste, the increase of which is accelerated by tightening environmental legislation: Stricter emission limits leading to higher concentrations of toxic residues in wastes, and clean-up programmes for contaminated industrial production or waste disposal sites are two examples illustrating that environmental problems are often not put to a final solution, but transferred to other media and areas of environmental concern. More pressure on currently existing waste management capacities will result from decisions to phase out waste incineration and disposal at sea on part of the United States and the EEC member states. The govemment of the Federal Republic of Germany has recently passed a regulation tripling the categories of wastes which are listed for special treatment as hazardous 23 , in a situation where already ten additional waste incineration plants are needed to provide capacity for the 1.6 million tons of flammable wastes of a total 5 million annually produced hazardous wastes 24 . Switzerland, which as a small country with heavy chemical industry exhibited particularly strong support

22 E.g. conceming the 1973 Convention on Intemational Trade in Endangered Species of Wild Fauna and Flora (CITES) JB. Heppes/E.J. McFadden, The Convention on Intemational Trade in Endangered Species of Wild Fauna and Flora: Improving the Prospects for Preserving our Biological Heritage, 5 Boston University International Law Joumal 1987, p.228, at 233.

23 See the govemmental magazine Umwelt No. 7, 1989, p. 329.

24 Richter, supra note 21, p. 20. Frankfurter Allgemeine Zeitung 4.1.1989. Frankfurter Rundschau 4.8.1988. 
for the elaboration of a global instrument to control hazardous waste exports, has increased its hazardous waste shipments to mostly EEC countries by 62 per cent in 1988, exports now covering one third of the annually produced 300,000 to 350,000 tons 25 . Projects in the hazardous waste generating countries to construct new treatment facilities and disposal sites regularly meet local protest. In addition, the costs of managing wastes in these countries are exorbitant if compared with the agreed rates which have become known for some of the recent dumping cases: Whereas in industrialized countries, costs for adequate treatment range from about 100 to 2,000 US $\$$ per ton 26 , waste dealers have been able to arrange for imports into developing countries in exchange for an average 30 to 50 US $\$$ per ton, with a correspondingly high margin of profit for the intermediary agents themselves 27 . The German Democratic Republic accepts hazardous wastes from other states in exchange for 50 to 80 US $\$$ per tons 28 .

Where hazardous waste import arrangements are being concluded with participation of developing countries' governments, the pressure on heavily indebted economies to earn foreign exchange matches the bottleneck situation with respect to waste management in the North29: The total volume of 15 million tons of wastes involved in an import project negotiated between the government of Guinea-Bissau and a group of US and European firms in May 1988 would have earned the country 600 million US \$, four times its Gross National Product and twice the amount of its foreign debt 30 . It would be simplistic, however, to generally relate the phenomenon to rising economic pressures on the developing world since much of the profits from waste transactions flow into private pockets rather than into the official state budget.

One of the best documented incidents of North-South waste movements is the journey of about 30,000 tons of toxic ashes from municipal waste incineration plants in Philadelphia, USA, on board of two ships - the "Khian Sea" and the "Bark". Similar to voyages of other hazardous waste ships such as the "Lynx" and "Zanoobia"31, "Karin B" and "Deepsea

25 Neue ZürcherZeitung No. 125, 3.6.1989 and No. 209, 10./11.9.1989.

26 Richter, supra note 21, p. 20. Frankfurter Allgemeine Zeitung 4.1.1989.

27 See the documentations of Greenpeace and Richter on export arrangements involving Benin, where an incredible 2,50 US \$ per ton had been agreed upon, and Cape Verde, Guinea, GuineaBissau and Congo.

28 Greenpeace, supra note 19, p. 84.

29 Intemational Herald Tribune 23.6.1988, citing UNEP official Jan Huismans on the positive impact of public awareness modifying debt-ridden Third World countries' cost-benefit-analysis on import proposals to favour long term environmental considerations.

30 Greenpeace, supra note 19, p. 26. Richter, supra note 21, p. 32. Due to intemational publicity, the project has not (yet) been implemented; the govemment claims to have cancelled the agreement.

31 Italian wastes on board of the "Lynx" sailing under Maltese flag were dumped in Puerto Cabello, Venezuela, in April 1987. On demand by the Venezuelan govemment, the 11,000 barrels which had caused significant hazards to the local population and watercourses surrounding the storage 
Carrier" ${ }^{32}$, this case is illustrative as it involves several private firms seated in different states, and it documents the incapability of industrialized countries and international organizations to keep track even of specific waste movements to which their attention has been called: The final fate of the greater part of the ashes on board of the "Khian Sea", which had left the port of Philadelphia in August 1986, is still unknown. In contravention of a national waste importation ban, the ship had dumped 4,000 tons of ashes in Haiti in early 1988. Since the "Khian Sea", which was renamed twice during the final stage of its journey from West Africa to Asia, in November 1988 anchored without its freight off the coast of Singapore, the ashes have either been dumped into the open sea, or - as the captain claims brought to an unnamed country after at least thirteen countries had refused permission for unloading the vessel. Three months earlier, 15,000 tons of toxic fly ashes that had been shipped overseas on board of the "Bark" had reentered the port of Philadelphia, returning it from the Guinean island Kassa, after a Norwegian-Guinean firm had imported it in fulfilment of a contract with a Norwegian transport company - itself a subsidiary of a United States company - falsely declaring it as "construction material" for the production of bricks. Upon the dumping, the Guinean government had reacted by arresting the Norwegian honorary consul Sigmund Stromme, who was involved in the transaction, until re-exportation by the transport company was ensured 33 . The resolution of this hazardous waste dumping incident, in the absence of legally binding international norms, was a resulted of encouraging efforts of collaboration between several governments and United Nations representatives.

\section{Key Provisions of the Convention}

A preliminary remark shall concern the scope of the Basel Convention, the title of which is misleading in this respect: The convention's draft has been amended at its last stage to cover not only "hazardous wastes", but also "other wastes": The first category comprises the wastes classified in Annexes I and III of the convention as well as wastes which one of the countries concerned by a particular movement considers or defines as hazardous; the latter category includes, in the true meaning of the words, all other wastes: Thus, all provisions apply equally to household wastes and to residues from the incineration of household

area were reexported by the Cypriot vessel "Makiri" which unloaded the already leaking barrels in Syria. From there, the Syrian-flag "Zanoobia" commenced its waste joumey over Greece to Italy, where the ship's crew was exposed to the wastes for months before the final unloading was permitted. See Greenpeace, supra note 19, p. 128-130.

32 These ships carried Italian wastes dumped in Nigeria back to Italy, see infra. IV. on the Nigerian dumping scandal.

33 For details on the joumeys of the Philadelphia fly ashes, see Greenpeace, supra note 19, p. 24 and 114; Richter, supra note 21, p. 30. 
wastes ${ }^{34}$. Although none of the exporting incidents to developing countries seems to have involved such "other wastes", this considerable expansion of the scope of the global regime adequately takes into account the growing problem of industrialized countries to manage their increasing amounts of household wastes. The following presentation of key provisions of the convention will nevertheless concern "hazardous wastes" as these have created the factual problems which prompted international co-operation in the area of waste movements.

Nuclear wastes are excluded from the scope of the convention if subject to "other international control systems"35. Currently, the International Atomic Energy Agency collaborates with other organizations towards a code of practice for international transactions involving nuclear wastes 36 .

\section{A Partial Ban of Hazardous Waste Exports}

A major motive on the side of UNEP for initiating the development of a global convention was to reduce the extent to which hazardous wastes are transferred particularly in the North-South direction. In the view of critics such as Greenpeace, however, the convention's substance amounts to a legalization and institutionalization of international waste trade which, although providing for a minimum of control, still ensures the existence of a future outlet for the hazards generated in industrialized countries into areas with less strict environmental standards 37 . The proposed total ban of hazardous waste movements to developing countries 38 , which would to a large extent relieve these countries from the pressure to take internal regulative or administrative action in order to control the influx of foreign wastes, has not yet been realized. It is only in the preamble that the "increasing desire for the prohibition of transboundary movements of hazardous wastes and their disposal in other states, especially in developing countries" is recognized. Art. 15 para. 7, however, will keep complete or partial bans an issue on the agenda of the future Conference of the Parties, as it provides that this issue is to be reevaluated three years after the convention's entry into force and periodically thereafter 39 .

34 Art. 1 in connection with Annex II of the convention.

35 Art. 1 para. 3.

36 Report of the Secretary-General on the Effects on the Environment of the Dumping of Nuclear Wastes, UNEP/GC.15/9/Add. 6.

37 Greenpeace press release of the German Section in Hamburg, 22.3.1989.

38 See the statement of the Jamaican representative in front of the Ad Hoc Working Group at its second session, UNEP/WG.186/3, p.5. The Netherlands and Sweden were the only industrialized countries which shared this position.

39 This provision was inserted upon proposal of Greenpeace, UNEP/WG.189/3 Annex I p. 37 with subsequent additions elaborated by UNEP, UNEP/WG.190/, p. 13. 
A partial ban of waste exports and imports has been introduced with respect to states which are not parties to the convention. Introduced into the draft at a late stage 40 , Art. 4 para. 5 in connection with Art. 11 allows transactions with non-parties only on the basis of other international agreements or arrangements which must conform to the Basel Convention's environmental standard. It will depend on the future specifications of this standard whether there is in fact a major loophole left for uncontrolled waste trade beyond the regime of Basel41. At least, the provision ensures that on each side of a transaction conforming to the terms of the Global Convention, general policy decisions must have been taken at the state level to set the frame for waste trade. This was not the case in any of the recent "dumping" incidents; in fact, so far only the United States have concluded bilateral agreements with their neighbouring states, and another regional arrangement is in place within the European Economic Community (EEC) 42 . As a consequence of an increased awareness of the environmental dangers resulting from inadequate waste management, as well as for reasons of publicity and collective pressure will developing countries - in particular the African states - be very reluctant to enter into such international agreements in the future.

For the relations between member states, the regulatory responsibility to introduce restrictions on waste movements beyond the controls embedded in the global convention lies with the individual states 43 . If national legislation prohibits the importation of wastes, any contravening transaction will regularly also imply a breach of international law: According to Art. 4 para. 1 (b), 2 (e), exporting states may not allow waste movements to states which have enacted such legislation. A number of developing countries have already banned waste imports 44 , among them Ivory Coast which determined the minimum penalty for any unlawful buying, selling, importing, transiting and depositing of toxic wastes to be 15 years of imprisonment 45 . The preamble of the convention simply recognizes the sovereign right

40 Originally proposed by a "subgroup on limited ban", UNEP/WG.189/, Annex I p. 10, and agreed upon at the Luxembourg session January/ February 1989, UNEP/WG.190/4, para. 34. Previous draft had contained different regimes for waste trade with parties and non-parties to the Convention.

41 See Brian Wynne, The toxic waste trade: intemational regulatory issues and options, 11 Third World Quarterly No.3 (1989), p. 120, at 139.

42 Infra. VI.

43 Art. 4 para. 11 explicitly allows Parties to introduce environmentally- or health-motivated additional restrictions on waste movements. As long as the discrepancies of waste management standards between industrialized and developing countries continue to exist, exporting countries will be able to even base a general complete ban of waste movements to developing countries on this provision. - In addition, an exporting state is of course not obliged under Art. 4 para. 9 to authorize a movement which will be in conformity with the Convention's formal and substantial requirements; the provision is formulated to restrict its discretion relative to a positive export decision.

44 Greenpeace lists 34 countries in Africa and Latin America which to its knowledge have banned waste imports by legislation or by official decree, supra note 19, p. 155 .

45 Law No. 88-651 of 7 July 1988, reprinted in 28 I.L.M. 391 (1989). 
of any state to ban the entry of disposal of foreign wastes, whereas the Federal Republic of Germany had proposed to specifically encourage developing countries to exercise this right 46 .

Upon proposal of the United States 47 , waste exporting to Antarctica is generally prohibited by Art. 4 para. 6 of the convention.

\section{Responsibilities Regarding Specific Waste Transactions}

Transboundary waste movements which are not per se prohibited are subject to several procedural and substantive requirements. In the following presentation of some major provisions, an emphasis will be on the distribution of regulatory and administrative responsibilities between exporting and importing countries which may reflect the background of diverging policy assumptions concerning international trade in hazardous materials: A liberalistic position stresses the sovereign right to undertake risk assessments on part of any risk-receiving country, whereas, on the other end of the spectrum, the assumption prevails that generators of hazards - and on the intemational level the states controlling them - shall not be enabled to transfer their responsibilities on private or governmental agents who are less equipped for adequate risk management. A third category comprises models which, based on the liberalistic approach, propose to balance unequal control capacities through specific mechanisms promoting such management abilities or even internationalizing the supervision of hazards trade.

\section{a) Transfer of Information}

Before any waste transaction may be initiated, all states concemed must have been involved in a complex informational procedure which is commonly termed "Prior Informed Consent"48. The state of export must ensure 49 that all transit states and the importing state receive in writing detailed information on the waste movement, the nature of the wastes and the projected method of its disposal, all private agents and all countries involved in the

46 UNEP/WG.189/3, Annex I p. 14 note 12.

47 UNEP/WG.190/4, p. 5.

48 Modalities of this approach have recently been introduced into international guidelines governing trade in chemicals, see the amended London Guidelines for the Exchange of Information on Chemicals in International Trade adopted by the UNEP Goveming Council by decision 15/30 of 25 May 1989, UNEP/GC.15/12 Annex I p. 161.

49 Either by its own notification orby requiring the generator or exporter to provide such notification, Art. 6 para. 1 of the convention. 
transaction, and finally on the agreement with the final disposer in the importing country 50 . The written consent of the transit and importing states as well as the importing state's confirmation of a contract between exporter and disposer, providing for environmentally sound management of the wastes, are necessary before the state of export may allow commencement of the movement. Whether transit countries should be treated on the same level as importing countries was one of the issues still strongly contested when the fifth - and last draft of the convention was elaborated51: The weaker consent procedure which had been proposed during the negotiations - a simple "Prior Informed Choice" mechanism - was rejected by representatives of developing countries 52 . It would have allowed a transit country to express its decision upon notification within a certain period of time, after which the waste consignment might have proceeded through the transit state's territory, if no response had been received53. Considering environmental and health hazards which may emanate from wastes already during their transport, as well as the unforeseeable course which waste movements have taken in the past leaving countries with risks at least until a new final destination had been chosen, there is good reason to require express consent from transit countries and to put no more pressure for a timely decision on them than on the state of import. The 60 day period for a transit country's response 54 is no more than an obligation to prompt reaction. Unless the transit country specifically concerned introduces modifications to the consent requirement 55 , its written consent is a precondition for the commencement of an export, no matter whether the response time limit has been exceeded.

The information transmitted by notification should enable the notified authorities 56 to assess risks connected with the transport and disposal of the wastes in question. For countries which lack own experiences and capacities in waste management, references to accepted standards of risk assessment are crucial: Apparently, the possibility to include information on the hazard classification and on the treatment standards which apply to a particular waste consignment in the state of export was not considered by the drafters of the convention. It would have provided the notified authority with a much more complete picture of the risks involved in a proposed acceptance of wastes than the required reference to UN hazard classifications 57 . Under Art. 4 para. 2 (f), the notification must "state clearly

50 Annex $\mathrm{V}$ lists all infornation which must be contained in the notification.

51 UNEP/WG.190/4, p. 8. Reservations to Art. 6 para. 4 in the now finalized version were made by several industrialized countries.

52 UNEP/WG.186/3, p. 8.

53 Art. 4 para. 4 of the Third Revised Draft Convention provided for such a Prior Informed Choice mechanism, UNEP/WG.186/3 Annex A p. 10.

54 Art. 6 para. 4,2 nd sentence.

55 Art. 6 para. 4, 4th sentence.

56 Each party shall designate "competent authorities" to implement the various mechanisms of the convention, Art. 5.

57 Annex V A uses the UN hazard classification system for the transport of dangerous goods, ST/SG/AC.10/1/Rev.5, United Nations, New York, 1988. 
the effects of the proposed movement on human health and the environment", but no agreed upon standards exist on which the notifier is to base his assessment. Outside expertise will have to support developing countries' "competent authorities" in examining the information received. The competences of the convention's secretariat are limited, in this respect, to informing parties upon their request about consulting firms or consultants 58 . Private firms had, in expectation of a newly developing field for their services, already taken an active interest in the negotiations for the various drafts.

The mutual transfer of information on a specific waste movement ends with the importing and transit countries' responses to the notifications; thereafter, a movement document carries details on the substances and on the persons involved until the transaction is completed59. To close the circle of documentation and enable some governmental control on the actual implementation of the projected export, one proposal by UNEP was to require that the final disposer inform the country of export on the receipt of the wastes and on the completion of their disposal60. Such reconfirmation would have been little more bureaucratic effort, but it would have provided the exporter's government with data which although not officially certified - might have served to influence future decisions as to the reliability of contracting private agents. In addition, states of export could have drawn upon a "feed-back" from the disposer in fulfilling their reporting duties to the Conference of Parties under Art. 13 para. 3 which, inter alia, cover information on "disposals which did not proceed as intended".

\section{b) Environmentally Sound Management of Exported Wastes}

Both the exporting and the importing countries are entrusted with obligations to ensure an environmentally sound management of wastes which have been moved across borders. The formulation of these obligations is remarkable: Parties are to not allow the export, or to prevent the import, of wastes, if they have "reason to believe that the wastes in question will not be managed in an environmentally sound manner" (Art. 4 paras. (e), (g)); they must not be positively convinced of the proposed transaction's environmental soundness. A request from Nigeria to rephrase the exporting state's obligation - notably not the one of the importing country - 61, to the effect that environmental consequences would have to be independently evaluated on the government level, was not accepted. The Convention's first draft had still contained the provision from Cairo Guideline62 No. 26 (f) according to

58 Art. 16 para. $1(\mathrm{~h})$.

59 Art. 4 para. 7 (c), Annex V B.

60 UNEP/WG.190/, p. 7.

61 UNEP/WG.190/4, p. 7.

62 Supra note 7. 
which exporting states had to "be satisfied" with the environmental soundness of waste treatment in the receiving country63.

The establishment of mechanisms which would still allow the exporting state a determination of the effects which a proposed movement might have on territory under foreign jurisdiction was never seriously discussed in the negotiations for the Basel Convention. A late, unconsidered UNEP proposal was to examine the need for including environmental impact assessments (EIA's) of waste disposal sites as part of the notification64, thus implying that the assessment were to be conducted upon initiative of the exporting country on foreign territory. More realistically, an EIA procedure could have been established under which collaboration with the importing government might have guarded the latter's sovereign rights. Another altemative would have been to tie exports to a certification issued by the state of import on the environmental soundness of the disposal facilities. This would at least have required government involvement in evaluating waste management conditions at the receiving end of transactions. - A verification of environmental standards in foreign countries already takes place under United States law, although not in the context of hazardous waste exports 65 .

A mere complementary function must be attributed to the convention's member states' duty under Art. 4 para. 8 to require environmentally sound management of exported wastes "in the State of import or elsewhere". It is left to the regulatory inventiveness of the states to find effective instruments of enforcement or of sanctions. The convention itself does not correlate this duty to the states' decision of allowing a transboundary waste movement.

These and a number of other provisions which make reference to the "environmentally sound management of wastes" 66 will remain toothless, if the interpretation of this standard is left to the individual states and to private exporters and disposers who, in their contract, must specify the terms of such soundness 67 . The envisaged elaboration of jointly agreed upon criteria and technical guidelines for waste management, which will then become an integral part of the convention, will be essential for the implementation of several additional provisions, e.g. on the reassuming of responsibility for wastes through re-importation, on the consequences of illegal waste movements or on the relation of other inter-

63 UNEP/WG.182/2, p. 10/11.

64 Note by the Executive Director of UNEP to the Third Meeting of the Working Group, Geneva November 1988, p. 7.

65 See Allegra Helfenstein, U.S. Controls on Intemational Disposal of Hazardous Waste, 22 The Intemational Lawyer 1988, p. 789.

66 The term is defined in Art. 2 para. 8 to mean "taking all practicable steps to ensure that hazardous wastes or other wastes are managed in a manner which will protect human health and the environment against the adverse effects which may result from such wastes".

67 Art. 6 para. 3 (b). 
national agreements to the Basel Convention. It was out of mere time constraint that a closer determination of waste management criteria has been postponed to the first meeting of the member states 68 which will be convened within one year of the treaty's entry into force69.

If the convention is indeed committed to restrict the transfer of hazards by complementing formal mechanisms with environmental safeguards, and not to ease an internationalization of waste disposal, then the work at this point is only half done: National approaches to waste management differ widely, and no common technical standards exist, yet. The Cairo Guidelines address only the administrative aspects of waste management; they call for international co-operation on the improvement of environmentally sound technologies; they do not mention harmonization of normative standards, although the Guidelines center around the notion of environmental soundness as well70. The European Communities' council directives dealing with waste treatment or disposal similarly obligate EEC member states to institute administrative controls and do not specify on the technical side71. In cooperation with the World Health Organization, UNEP has published policy guidelines and a code of practice on hazardous waste management 72 which presents governments with options for the formulation of national management policies; their guidance remains on a very general level, however. Consequently, the process of elaborating criteria and guidelines on the Basel Convention's environmental standard will be a timely first effort to harmonize existing national waste management practices.

\section{c) Re-import of Wastes and Consequences of Illegal Traffic}

In determining duties to reassume responsibility for wastes which have already left the country of their generation, the convention distinguishes between movements which conform to its provisions and transactions which, for various reasons, qualify as "illegal traffic". The obligation to ensure re-importation of wastes by the exporter into the state of export lies entirely with the latter state, if a consented movement "cannot be completed in accordance with the terms of the contract" (Art. 8) and no altemative, environmentally safe disposal arrangements can be made. Viewed in the context of the convention's genesis, this

68 Art. 4 para. 2 (e) and para. 8. The postponement was suggested at the November 1988 Geneva meeting, UNEP/WG.189/3, p. 11, and approved at the following Luxembourg meeting, UNEP/WG.190/4, p. 20.

69 Art. 15 para. 1.

70 see Guideline 10,12 for the general control of hazardous waste disposal and Guidelines 2, 26 for their transfrontier movement.

71 Council Directives 75/439/EEC, 75/442/EEC and 76/403/EEC.

72 WHO Regional Publications European Series No. 14, Management of Hazardous Wastes, Copenhagen 1983. 
provision embodies a surprisingly strong allocation of responsibilities to one - the exporting - state in cases where in fact several governments have been involved in approving of a waste movement. In the first draft, it was initially considered to simply institute a general duty of all states to co-operate in search of altemative disposal arrangements, and a complementary duty of the state of export not to "oppose, hinder or prevent the return" of the wastes into its territory 73 . Consensus on diverging altemative proposals was not found until the Luxembourg meeting in early 1989 , when it had become clear that illegally conducted waste movements would be regulated separately74. Under Article 9, now covering the consequences of "illegal traffic"75, the exporting state has to merely co-operate with the state of import, if the illegality is the "result of conduct on part of the importer or disposer". If, on the other hand, the illegality can be attributed to the exporter or generator, then one of these agents - or, if necessary, the state of export itself - is to take back the wastes, or the state or export must ensure an altemative way of disposal in conformity with the convention.

On first sight, the "illegal traffic" article seems to determine quite precisely who, and by which action, has to bear the consequences for incorrectly conducted exports. In individual cases it may be difficult, however, to apply the strict division between illegal conduct of importer or disposer on the one hand, and of exporter or generator on the other hand. False declarations of wastes (e.g. as "construction material", as in the case of the Philadelphia incinerator ash imported into Guinea) or other fraudulent action may well be collusively arranged for by agents on both sides of the transaction. Difficulties to prove the accountability for misconduct, especially if several firms are involved in a waste movement, might have been alleviated by a primary obligation of the state of export to ensure re-import or other ways of sound disposal, exempting the case where illegality on part of the importer or disposer can be clearly established. For such constellations, Art. 9 para. 4 contains a mere duty of the parties concerned to co-operate. In addition, the practicability of Art. 9 para. 3 , attributing a duty to ensure sound disposal to the state of import is highly questionable, if the latter is a developing country with no infrastructure to guarantee adequate waste treatment.

UNEP/WG.182/2, p. 21.

74 UNEP/WG.190/4, p. 26. For the altematives, providing for the re-importation as arranged collectively by all countries concemed, or by private agents involved respectively by the exporting state see UNEP/WG.189/3.

75 The concept of "illegal traffic" is specified in Art. 9 para 1, covering movements without notification or consent, movements which are consented as a result of "falsification, misrepresentation or fraud", movements of mislabelled or wrongly declared substances and, finally, "deliberate disposal in contravention of this Convention and of general principles of international law". 
Illegal traffic in wastes is, under Art. 4 para. 3, considered criminal; the Parties have discretion by which appropriate means they "prevent and punish" conduct deemed illegal76.

\section{d) Reduction of Transboundary Waste Movements}

In the last months before the scheduled adoption of the final Convention, UNEP started to present its own strong policy preferences for the developing instrument and withdrew from the position of a mere administrative forum for the negotiations. Addressing the third session of the working group in November 1988, the organization's executive director Tolba clarified what in UNEP's view were the aims of a global convention77: A hierarchy of three regulatory goals headed by the elimination of the need for hazardous waste movements, to be achieved by a major reduction of waste generation - notably an issue of national waste management which exceeds the mandate, if strictly interpreted, on which UNEP based its work towards the Cairo Guidelines and subsequently towards their further development into a global binding instrument 78 . Secondly, the provisions of the convention, according to the UNEP position, were to permit transboundary movements only if the disposal of wastes away from the place of their generation was "equally or more environmentally sound"; movements should be reduced to a minimum by introducing correspondingly tight conditions for approval. The management of wastes which under these two principles remain for transboundary movements was to be subjected to the "most environmentally safe conditions available".

Realistically, UNEP at that time could not hope for a realization of its initiative: Although the draft already contained principles on national hazardous waste management policy, it was heavily oriented towards a procedural approach in controlling international waste trade. As the above analysis of environmental standards embedded into the final Convention may illustrate, the instrument by far fails to ensure a best-available-management standard for exported wastes, or to close the gap in environmental safeness legally required for waste treatment and disposal in the country of generation as compared to the waste importing country. The aim of reducing occurrence and extent of waste exports has been embodied only in an indirect way, consistent with the preamble which states that "enhanced control of transboundary movement ... will act as an incentive for ... the reduction of the volume of

76 Art. 9 para.5. Stronger proposals to introduce "severe punishment" had been submitted by the developing countries belonging to the Group of 77, UNEP/WG.189/3, p. 23.

77 Report of the Third Session, UNEP/WG.189/3, p. 2, 3.

78 UNEP's mandate to develop the Cairo Guidelines followed from the "Montevideo Programme for the Development and Periodic Review of Environmental Law", adopted by decision 10/21 of the UNEP Goveming Council on 31 May 1982. When it adopted the Cairo Guidelines, the Goveming Council authorized UNEP to convene experts to prepare a binding treaty without itself giving further policy directives, see GC decision 14/30 of 17 June 1987, UNEP/GC.14/26, Annex I p. 63. 
such transboundary movement". Although parties have to report annually on their efforts to achieve such a reduction79, their corresponding substantive obligation is merely to "review periodically the possibilities" for this end80. An economic waiver, attached to the not yet specified ecological standard used throughout the convention, seems to be inherent in the duties under Art. 4 para. 2 (d): A reduction of exports to the "minimum consistent with the environmentally sound and efficient management" of wastes allows exporting states to introduce arguments of their own narrowing waste management capacities; in addition, it is dynamic at best in favour of waste transfers, if - with the help of assistance mechanisms under the convention itself - the conditions for an environmentally tolerable disposal are being improved in potential waste recipient countries. The provisions addressing issues of a preventive and nationally self-reliant waste policy, namely duties to ensure the minimization of waste generation and the availability of disposal facilities within the wastegenerating country 81 may - if they prove to be effectively enforceable - promote a reduction of transboundary waste movements. The convention's failure, however, to directly convert the expected effects into a dynamic export reduction clause must be criticized in particular, since UNEP had submitted a clearly formulated proposal on this matter to the negotiating state representatives 82 .

\section{Support Measures and the Role of the Secretariat}

A survey of developing countries' legislation and infrastructure concerning hazardous waste management which UNEP conducted in 1983 confirmed that comprehensive waste management schemes existed in virtually none of these countries, including the newly industrializing states which were already generating their own hazardous waste dilemma83. The situation has not much improved since: The lack of related regulations, adequate treatment and disposal facilities and of trained manpower in most developing countries necessitates active support from countries with an established waste management system even if the dimension of waste imports from the industrialized world is not taken into account 84 .

79 Art. 13 para. 3 (b) (iv).

80 Art. 4 para 13, inserted upon proposal by Tunisia, UNEP/WG.190/3, p. 6.

81 Art. 4 para. 2 (a) and (b).

82 Note by the Executive Director of UNEP to the Geneva meeting November 1988, p. 4: "The Conctracting Parties shall undertake to ensure the continuous reduction of the amount of hazardous wastes which are exported to other countries, in particular developing countries ...".

83 UNEP/WG.95/2: "Transfrontier Movements of Hazardous Wastes with Regard to Developing Countries", p. 4.

84 See World Commission of Environment and Development, supra note 12, p. 227. UNEP 1989 State of the World Environment, p. 39. 
The working group preparing the draft convention operated under the expectation to "give special consideration to the situation of developing countries" and to develop appropriate assistance mechanisms which should both enhance their general capacity to safely handle wastes and foster their ability to assess information on hazardous wastes transmitted prior to specific waste movements85. The finalized convention contains several general duties towards international co-operation, providing for information exchange on management practices and technical standards, joint monitoring of adverse effects from waste management and for joint development of low-waste technologies and of technical guidelines 86 . In addition, the special needs of developing countries are addressed by Art. 10 para. 2 (d), mandating active co-operation in the transfer of technology and management systems, as well as the co-operative development of technical capacity to deal with wastes. To this end, it is envisaged to establish regional training and technology centres87. A revolving fund to be decided upon by the parties shall cover interim financial assistance in cases of emergencies arising from the transfrontier movements itself or from the subsequent disposal of wastes 88 .

In several incidents where developing countries received proposals by foreign corporations conceming the importation and treatment of wastes, governments have turned to United Nations agencies requesting for assistance to obtain information on particular hazardous substances and their regulative control in other countries. UNEP's INFOTERRA system which facilitates access to environmental information, and the International Register of Potentially Toxic Chemicals (IRPTC) 89 both have helped to evaluate risks involved in such proposed operations by lending their own expertise on environmental hazards to developing countries' authorities and by referring them to other organizations or private research institutions. UNEP and the International Atomic Energy Agency (IAEA) were also involved in assessing the consequences of hazardous waste dumping in African countries, for example in the Guinean and Nigerian incidents 90 . In the negotiations for the global convention, representatives from Group of 77 member countries stated their concern that the future convention secretariat should be installed with effective powers to provide support to developing countries and to "ensure transparency" of hazardous waste movements 91 . When the prospect of unusually broad functions of the secretariat had aroused suspicion among other states' representatives, UNEP hastened to clarify its understanding that no competences to

85 See the statement of UNEP's executive director addressing the first session of the working group, UNEP/WG.182/3, p. 5.

86 Art. 10 paras. 2 (a), (b), (c) and (e).

87 Art 14 para.1; the question of funding mechanisms for these measures has not yet been resolved.

88 Art. 14 para.2. The UNEP executive director's proposal to schedule decision on both funding mechanisms to the first meeting of the parties, UNEP/WG.190/3, p. 12, has not been incorporated.

89 For a presentation of INFOTERRA and IRPTC, see UNEP 1988 Annual Report, p. 34-39.

90 On the Nigerian incident see Richter, supra note 21, p. 41.

91 UNEP/WG.186/3, p. 8. 
actively inspect, monitor or verify specific movements were to be conferred upon the secretariat, but it would be empowered to assist the convention's member states in finding appropriate outside expertise, including resources within the United Nations system 92 . Art. 16 specifies the areas in which the secretariat may perform such informational assistance, complementing the typical secretariat tasks of coordination and reporting. In the area of illegal waste movements, it will possibly play a more active role as it is called upon to assist, upon request, in the identification of cases of illegal traffic. This, however, does not constitute a mandate for independent investigations of illegalities (as defined in Art. 9) or other conduct in breach of the convention 93 . The secretariat only has access to the information transmitted between the states under the Prior Informed Consent procedure, if a state involved in a particular movement has requested so94. Proposed provisions requiring that copies of each exchange of information prior to an export be sent to the secretariat 95 would have been the sole basis for a concentrated monitoring of developments in international waste trade, for which the secretariat now depends on adequate reporting from member states.

Another assigned function must be viewed critically: If the secretariat is to compile and circulate information conceming authorized national waste disposal sites and facilities among the parties to the Convention96, it may - contrary to its own policy objectives aiming at the minimization of transboundary movements - function as facilitator of a further internationalization of waste management. Again, it does not possess the express competence to conduct its own assessment on the environmental safeness of such disposal sites; accordingly, the secretariat will have limited ability to comment upon the national environmental standards which formed the basis for authorization.

\section{African Positions}

By their demonstrative refusal to sign the Basel Convention in March 1989, the member states of the Organization of African Unity (OAU) sought to document that the compromise laid down in the treaty is inacceptable to them: It divides between exporting and receiving countries' regulatory and administrative burdens for a problem which, according to the officially projected African view, is generated and must, therefore, be solved to a more substantive part by the industrialized countries. While a common policy approach of African

92 UNEP/WG.191/2, p. 5, 6.

93 According to Art. 19, parties initiate the circulation of infornation on breaches of obligations.

94 Art. 13 para. 4.

95 See UNEP/WG.186/3, Annex A p. 11 and UNEP/WG.189/3, Annex I p. 19, reporing on a comment by the Federal Republic of Gernany on the problem of confidentiality of infornation, and mentioning the general reservation of the United States representative to such a provision.

96 Art. 16 para. 1 (f). The member states' reporting duties, which are to be fulfilled by transmittal through the secretariat, cover infornation on available disposal options, see Art. 13 para. 3 (g). 
countries remains yet to be elaborated ${ }^{97}$, several declarations and national regulations have been passed since mid-1988 which address the issue; these documents, together with the proposals which representatives of African states raised in the negotiations for the UNEP draft treaty, contrast against the participation of some African governments in hazardous waste transactions: The latest example of a discrepancy between collective verbal statement and individual state conduct in this respect concerns Angola, which is reported to have concluded preliminary contracts with a Swiss waste broker on the installation of three waste incinerators in exchange for 2 billion US $\$ 98$.

The OAU Council of Ministers at its forty-eighth ordinary session in May 1988 dealt with the issue of waste dumping in Africa - at the time, transports to Guinea99, GuineaBissau100 and Benin101 had become public. A joint resolution on the "Dumping of nuclear and industrial wastes in Africa"102 identifies "transnational corporations and other enterprises from industrial countries" on the one hand and "African countries" on the other hand as agents in the "growing practice" of waste dumping, which it declares a "crime against Africa and the African people". The OAU member states are called upon to withdraw from all waste transactions which are already agreed upon or in the process of being arranged, and the OAU secretary-general is requested to collaborate with intemational organizations towards the installation of appropriate monitoring and control mechanism for African countries. The resolution demands for a clean-up of already contaminated areas by the private corporations involved in waste dumping and invites member states to participate in the UNEP negotiations for the global convention.

At the 1988 OAU summit, Nigeria was the most outspoken critic of waste exports to Africa, calling for a concerted action on the issue and condemning the recent incidents as an "attack on the dignity of Africa and to the integrity of our territories"103. Only days after

97 An OAU-sponsored conference is planned for late 1989 to hold consultations on the question of signing the Basel Convention. A possible outcome might be that the African countries finally agree on a collective waste import ban, complementing signature of the global treaty in order to benefit from its provisions on illegal traffic and technical, financial as well as administrative assistance.

98 See Greenpeace, supra note 19, p. 17/18, and die tageszeitung, 21.12.1988. On the inconsistency of African states' conduct, see Richter, supra note 21, p. 9. 57/58.

99 Supra II.

100 Supra note 30.

101 Four members of the Benin cabinet were reported to have signed a contract on 12 January 1988 on the importation of an annual one to five million tons of European industrial wastes. The contract was cancelled in September 1988 upon initiative of the president of Benin, Kérékou. Later rumors concerned negotiations for the importation of nuclear wastes from France, see Richter, supra note 21, p. $25 / 26$.

102 OAU Council of Ministers Resolution 1153 of 23 May 1988, reprinted in 28 I.L.M. 567 (1989).

103 The Nigerian Minister for Extemal Affairs Ike Nwachukwu as cited in Daily Nation, Nairobi, 25.5.1988. 
the adoption of the OAU resolution, Nigeria was embarrassed by the revelation of another scandal involving 3,800 tons of Italian hazardous wastes which had been dumped on a private compound in the village of Koko on the Nigerian coast between August 1987 and May 1988. Although the Nigerian government itself had not participated in the dumping, its preceding role as initiator of the OAU joint statement compelled the government to take rather drastic action by announcing that the responsible agents would face the death penalty 104 , and by breaking off diplomatic relations with Italy which initially refused to take back the wastes 105. Meanwhile, the toxic waste barrels have been transported back to Italy where unloading had to be commissioned by order of the central government against the protests of dock workers and the local administration 106.

Since the phenomenon of waste dumping which continued to be revealed by European nongovernmental organizations throughout the summer of 1988 seemed to concentrate in the West African region, the 11 th summit of the Economic Community of West African States (ECOWAS) from 24 to 25 June 1988 in Lomé, Togo, was again devoted primarily to discussing this issue. Togo itself had been one of the first African countries to offensively counter rumors about of ficial toxic waste import agreements 107 by issuing a declaration on 20 May 1988 which, pointing to an arising awareness within the country concerning environmental protection, condemns industrialized countries' attempts to save their own populations from dangers of "nuclear and toxic wastes" and instead to irrespectively put at risk the future of a continent already stricken with natural catastrophes, deteriorating terms of trade and the burden of external debt 108 . The ECOWAS meeting produced a resolution in which the 16 member states agreed on the promulgation of laws making it a criminal offence to "take part in any act that facilitates the dumping of nuclear and industrial waste". The resolution additionally calls upon the industrial states to ensure the safe elimination of their toxic wastes and to prevent their exportation to other countries 109.

Senegal took initiative next, requesting the UNEP secretariat to consider the development of a Protocol on Hazardous Waste in the framework of the 1981 Abidjan Convention for Co-operation in the Protection and Development of the Marine and Coastal Environment of

104 Zürcher Zeitung No. 137, 16.6.1988.

105 Richter, supra note 7, p. 41.

106 For a documentation of the re-export of Italian wastes from Nigeria see Greenpeace, supra note 19, p. 130 - 133. Frankfurter Rundschau 31.8.1988, 2./3./15./17./19./21./24.9.1988.

107 According to Greenpeace information, Togo's minister of health denounced statements of an Italian waste broker on the existence of Togo's written consent to the importation of hazardous waste. He admitted, however, that in February 1988 a Togolese businessman had been authorized in principle to import industrial residues and pharmaceutical products. See Greenpeace, supra note 19, p. 43.

108 Reuter Nachrichtendienst, 21.5.1988.

109 See Keesing's Contemporary Archives Vol. XXXIV, October 1988, p. 36252. 
the West and Central African Region. It was then decided to convene an African Ministerial Conference on Hazardous Wastes which took place from 26 to 27 January 1989 in Dakar, Senegal, in the context of two other regional meetings on marine environmental protection. In the course of the conference, the policy positions of the represented European and African governments proved to be so divergent that the meeting culminated in a diplomatic disaster, with none of the proposed joint declarations adopted except for one "strongly encouraging all developing countries" to participate in the Basel Conference110. UNEP had suggested to consider several options for regional legal instruments, possibly as protocols under the Abidjan Convention or under the future global convention on transboundary waste movements: The strongest measure proposed was an "outright ban on all imports of hazardous wastes into the region or sub-region", with the alternative of a phased ban gradually reducing the amount of imported wastes 111 . Both suggestions, in retrospect, lacked sensitiveness with regard to the evolving collective African approach on international trade in hazardous waste. Although in all declarations preceding the Dakar conference, African governments had committed themselves to refrain from any involvement in the importation of wastes, the thrust of their joint action was to demand from the industrialized countries measures to prevent, from the source of the threat, further exports. Neither at Dakar nor at the Basel Diplomatic Conference were they willing to accept regulatory responsibilities without the guarantee of reciprocity between North and South. With the phased ban suggested by UNEP, African governments would have admitted the existence of officially consented waste imports - for which some of them had just been in an uncomfortable position to render explanations in the preceding OAU and ECOWAS summits - and, worse, created legal terms for their future continuation. A resolution of the Dakar conference to adopt a regionally binding instrument on a waste import ban thus went out of reach, when the European countries refused to agree, in turn, to a general prohibition of exports to African countries. In the meantime, a new initiative on part of the EEC has been to incorporate a clause banning waste movements to developing countries into its Lomé development co-operation agreement with 66 states in Africa, the Caribbean and the Pacific, if the latter commit themselves to likewise prohibit the importation of wastes from third, non-EEC countries 112 . Since the reaction of the concerned developing countries is reported to be favorable, a way out of the dilemma of the Dakar and Basel conferences might be to jointly institute modifications of the global regime in the framework of multilateral development co-operation.

During the Dakar conference, a number of issues were raised which, at the final session of the working group preparing the global convention and at the Basel Diplomatic Conference itself, the OAU and individual African states elaborated into proposals to amend the con-

110 Frankfurter Rundschau 30.1.1989; for the proposed final joint declaration see UNEP/IG.81/L.1.

111 UNEP/IG.81/L.1, p. 5.

112 Frankfurter Allgemeine Zeitung 5.6.1989; Süddeutsche Zeitung 7.6.1989. 
vention's draft. Among them were the prohibition of waste movements to countries with national import bans or to non-parties of the convention, the need for technical co-operation and specific technical assistance to developing countries, efforts to minimize hazardous wastes at the source of their generation and the duty of the exporting state to take back illegally transferred wastes 113 . Since most of these issues have found appropriate consideration - an exception is the state of import's share in finding an environmentally sound solution for illegally imported wastes 114 -, a resolution of the conflict over the signature of the Convention which the OAU has planned to address through negotiating for a common African position 115 will be tied to further progress conceming a general ban on hazardous waste trade with developing countries.

\section{The regulatory Context: Other Initiatives}

Controls on transboundary waste trade may be instituted on several regulatory levels, ranging from the global approach to regional, bilateral and national instruments. The Basel Convention allows member states to conclude international agreements on such other levels amongst each other or even with states non-parties to the convention, if they "do not derogate from the environmentally sound management of hazardous wastes and other wastes" as required by the global instrument. Agreements concluded prior to the convention's entry into force shall remain unaffected if "compatible with" the environmental standard of the global instrument (Art. 11). A number of existing international regulatory initiatives and national laws on the exportation of wastes form the context which the drafters of the convention had to take into account since the industrialized countries would not have been willing to adopt a regime substituting rather than complementing the rules and international obligations to which they had already subjected themselves.

The Organization for Economic Co-operation and Development (OECD) has conducted extensive activities in the field of waste management 116 and, since 1981 , specifically on the related transboundary aspects. Four decisions of the OECD Council have been issued promulgating principles according to which member states shall conduct their hazardous

113 A detailed listing in contained in "Proposals and positions of the African states during the negotiations of the Basel Convention (...) and the status of their incorporation into the Basel Convention", paper prepared by the UNEP Secretariat.

114 See supra III. 2.c).

115 the OAU Council of Ministers at its forty-ninth ordinary session has again called for such negotiations.

116 The organization established a Waste Management Policy Group in 1974. The OECD Council Recommendation C (76) 155 on a Comprehensive Waste Management Policy, adopted on 28 September 1976, calls for a reduction at source of the total quantity of waste generated, for maximum recycling efforts and for the safety in transport and disposal of hazardous wastes. 
waste transfers within and, with certain modifications, outside of the OECD area ${ }^{117}$, the premise for an evolving system being that the "efficient and environmentally sound management of hazardous wastes may justify some transfrontier movement of such waste in order to make use of appropriate disposal facilities in other countries"118. Waste movements to member countries are governed by a not further specified principle to ensure adequate and timely information to the authorities of all states concerned119, whereas for exports from the OECD area to third countries, the importing countries' consent upon the receipt of a more detailed notification - covering inter alia legislation in the country of origin on waste disposal methods - is required120. Shipments to third countries must, in addition, be "directed to an adequate disposal facility", and the waste generator should generally be required to "reassume responsibility for the proper management of its waste, including if necessary the re-importation of such waste, if arrangements for safe disposal cannot be completed"121.

The project to develop an internationally binding agreement on the basis of these decisions and recommendations 122 has not left the drafting stage, yet, and it is questionable, whether the OECD intends to finalize an additional multilateral instrument paralleling the Basel Convention 123. On definitional and technical questions, there was substantive input from the drafting efforts to the UNEP convention, the annexes of which are to a large extent drawn from a respective OECD council decision 124.

For the member countries of the European Economic Community (EEC), Council Directive 84/631/EEC on the Supervision and Control within the Community Countries of the Transfrontier Shipment of Hazardous Wastes 125 requires notification by the exporter to the

117 Smets, supra note 15, p. 16. For another summary of the decisions' substance see Helfenstein, supra note 65, p. 785.

118 Preamble of the Council Decision and Recommendation of 1 February 1984, C(83)180, and of the Conclusion and Recommendation of the OECD Conference on International Co-operation Conceming Transfrontier Movements of Hazardous Wastes, held in Basel from 26 to 27 March 1985, see OECD C (85) 100, Appendix p. 3.

119 OECD C(83)180 (Final), Principle 5. The Decision and Recommendation is reprinted at 23 I.L.M. 214 (1984).

120 OECD C(86)64 (Final) of 5th June 1986, 25 I.L.M. 1010 (1986).

121 OECD C(83)180 (Final), Principle 3.(c).

122 The elaboration of an OECD convention on transfrontier waste movements before the end of 1987 was decided upon by Council Resolution C(85)100 of 20th June 1985.

123 On the progress of the OECD Draft Convention before the adoption of the Basel Conference, see the reports in Intemational Environment Reporter, 9 (1986) p. 32, 111, 238, 10 (1987) p. 57, 199 , 314, 580 and 11 (1988), p. 220.

124 OECD Decision of the Council on Transfrontier Movements of Hazardous Wastes C(88)90 (Final) of 27th May 1988, 28 I.L.M. 257 (1989).

125 Directive 84/631/EEC has been amended by Council Directives 85/469/EEC, 86/279/EEC and $87 / 112 /$ EEC. 
recipient country, inter alia containing information on the existence of a contractual agreement with the importer who must have adequate technical capacity to dispose of the wastes without causing health or environmental hazards. Hazardous waste movements to countries outside of the EEC126 may not be initiated without the consent of the importing country. Implementation of the EEC directive which, in its amended version, has been applicable since January 1987, is delayed in most member states 127 .

The government of the Federal Republic of Germany has recently enacted a regulation on the transboundary movement of wastes 128 in fulfilment of its obligations under EEC law and of its own waste legislation 129. Under Section 13 of the Waste Act, exporters of wastes require authorization which may only be issued, if there is no capacity for treatment or disposal within the territory of the Federal Republic130. In addition, the authority issuing the export permit must be provided with certifications by the importing state on the adequacy of management upon receipt of the wastes, and by transit states on their consent to the movement. The environment- and health-related express requirement for waste exports concerns adverse effects only in the Federal Republic itself; however, since the authorizing agency possesses discretion whether to grant permission to the export, there is some room for a consideration of environmental hazards that might emanate from the wastes in the country of importation 131 . Both on the federal and on state level, it is the officially declared policy that no export authorizations at least for hazardous wastes will be issued if the wastes are destined for disposal in a developing country 132 .

126 Movements to non-EEC member countries are covered by Council Directive 86/279/EEC of 12 June 1986.

127 The EEC Environmental Affairs Commissioner Clinton Davis spoke to the European Parliament on 15 September 1987, criticizing that at the time of the accident of the British ferry "Herald of Free Enterprise", which had also carried barrels of hazardous wastes, none of the EEC member states had enacted legislation to implement the directive. As of May 1988, only Belgium and Denmark had complied with their obligation of implementation, although the amended directive has been applicable in member countries since January 1987. See Intemational Environment Reporter 10 (1987), p. 496 and 11 (1988), p. 325.

128 Verordnung über die grenzüberschreitende Verbringung von Abfällen (Abfallverbringungsverordnung) vom 18. November 1988, Bundesgesetzblatt 1988 I 2126, 2418. For a summary and comment, see Rainer P. Eckert, Die Abfallverbringungsverordnung vom 18.11.1988, Neue Zeitschrift für Verwaltungsrecht 1989, S. 125.

129 Gesetz über die Vermeidung und Entsorgung von Abfällen vom 27.8.1986, Bundesgesetzblatt 1986 I 1410, 1501.

130 Section 13 para. 4 a) contains two exceptions with respect to this "principle of waste management within the country of its generation": an efficiency clause and a clause accounting for diverging planning on the federal state level.

131 For detailed argumentation see Philip Kunig, Rechtsfragen der Abfallausfuhr in die Dritte Welt, Natur und Recht 1989, S. 19.

132 Greenpeace, supra note 19, p. 123 and Kunig, previous note, p. 20. 
A regional regulatory system for hazardous waste movements is in place in North America. The United States has been controlling hazardous waste exports since 1980 , initially by regulation of the Federal Environmental Protection Agency (EPA) mandating only minimal annual notification to EPA133. A legal basis for more stringent hazardous waste export controls was created in 1984134, and two years later, EPA's implementing regulation was finalized135. The resulting regime submits exports to a "Prior Informed Consent" requirement and to an elaborate notification procedure, but specifically allows for modifications, if a hazardous waste movement is conducted on the basis of international agreements. Shortly after the promulgation of the final EPA regulation, the United States entered into bilateral treaties with both of its neighbouring states: The "Agreement Between the Government of Canada and the Government of the United States of America Conceming the Transboundary Movement of Hazardous Waste" of 28 October 1986136 introduces a tacit consent procedure ("Prior Informed Choice"), allowing the waste shipment to be initiated, if the informed state of import has not raised objections to a proposed movement within 30 days upon notification 137 , and obliges the country of export to readmit wastes, if the importing country decides to return a particular shipment 138 . A corresponding treaty was concluded with Mexico139, some months after the discovery of a dumping scandal involving two American businessmen who were charged with unlawfully exporting more than 100,000 gallons of liquid waste and additional solid wastes, and disposing them near the Mexican village of Tecate140. It forms an integral part of the comprehensive United States-Mexican 1983 Agreement to Cooperate in the Solution of Environmental Problems in the Border Area141 and, in addition to notification, readmission of rejected wastes,

133 See Helfenstein, supra note 65, p. 77; for a summary of the rules preceding the current U.S. hazardous waste export regime, see Federal Register Vol. 51, No. 153, p. 28664.

134 By way of the 1984 Hazardous and Solid Waste Amendments, a new Section 3017 was added to the Resource Conservation and Recovery Act (RECRA) which itself amends the Solid Waste Disposal Act.

13540 CFR Parts 260, 261, 262, 263 and 271, Federal Register Vol. 51, p. 28683. For a summarizing report see Environment Reporter 1986, p. 556 and Intemational Environment Reporter 9 (1986), p. 319.

136 Referenced in 26 I.L.M. 593 (1987).

137 Art. 3 (d).

138 Art. 6.

139 Agreement on the Transboundary Shipments of Hazardous Wastes and Hazardous Substances of 12 November 1986, reprinted in 26 I.L.M. 12 (1987). See the commentaries by Denise Maes, Transboundary Waste Dumping: The United States and Mexico Take a Stand, 27 Natural Resources Joumal (1987), p. 941 and Elizabeth C. Rose, Transboundary Harm: Hazardous Waste Management Problems and Mexico's Maquiladoras, 23 Intemational Lawyer (1989), p. 223.

140 Maes, previous note, p. 942; International Environment Reporter 9 (1986), p. 399.

141 Agreement of 14 August 1983, reprinted in 22 I.L.M. 1025 (1983), with additional special agreements annexed on sanitation, on the discharge of hazardous substances along the boundary and on transboundary air pollution resulting from copper smelters. On the whole cooperation package see Sinclair, The Environmental Cooperation Agreement between Mexico and the United States: A 
monitoring and inspection requirements, requires the country of export to ensure the cleanup of areas contaminated by illegal waste exports and provide compensation for any damages caused 142. Neither of the bilateral treaties concluded by the United States contain reference to the environmental soundness of the final hazardous waste treatment or disposal operations. It is therefore questionable, whether those agreements are "compatible with the environmentally sound management" of wastes as required by the Basel Convention and, in consequence, whether the United States as a future party to the global convention would be able to uphold its bilateral treaties in their current form. In its declaration to the Basel Conference, the United States government has voiced support for the global control of hazardous waste exports and announced that it would give the convention "full and careful consideration" as well as strive towards legislation prohibiting all waste exports outside of bilateral agreements 143 . Since July 1988 , several bills on the further restriction or banning of hazardous waste movements from the United States have been introduced in its House of Representatives 144 .

\section{Concluding Remarks}

The challenge to formulate international consensus on responsibilities for the unwanted byproducts of modern industrial society will continue to exist. The Basel Convention contains some flexibility to conduct such further consensus building in the framework of its own regime. Despite its current inadequacies on central issues, the global treaty may prove to be a step forward in closing the outlet of states with advanced environmental controls. To this end, however, it will be crucial that the states which have been worst affected by the hazardous waste export streams join the global regime and lend momentum to the future member states' negotiations, e.g. on liability questions, and on the specification of the conventions's environmental standard. Viewed in comparison with other efforts to control hazardous waste trade, much more than an international minimum consenus has been reached and adopted at Basel, and prospects of continuing illegal waste trade practices or of an increasing misuse of recycling clauses question the effectiveness of controlling waste management on all regulatory levels. On the only radical solution to the waste dilemma, the minimization of its generation, little progress will emanate from the Global Convention: Its most valuable contribution could have been to conserve the pressure on management capacities in the same place where public tolerance of hazardous waste generation may undergo changes as its effects remain present. Consequently, the reduction of trans-

response to the pollution problems of the borderlands, 19 Comell Intemational Law Joumal (1986), p. 87.

142 Art. XIV para. 2.

143 Final Act of the Basel Conference, UNEP document p. 23.

144 Greenpeace, supra note 19, p. 112-114. 
boundary waste movements, the aim of which goes beyond a concern for health and environmental protection in waste receiving countries, is still a goal which can most realistically be implemented on the national level. 


\title{
ABSTRACTS
}

\section{Fighting Transboundary Waste Streams: Will the Basel Convention help?}

\author{
By Susanne Rublack
}

The increasing occurrence of hazardous waste exports from industrialized countries mainly to African countries has coincided with efforts on the international level to create norms which subject such transactions to controls. The first binding instrument on transboundary movements of hazardous wastes was adopted at the Basel diplomatic conference in March of 1989. Since the African countries refused the signature of the Basel Convention, because in their view it does not go far enough to prevent incidents of waste dumping in the developing world, it is still uncertain what contribution to a co-operative solution of the problem this instrument will be able to make. The article attempts a first analysis of the convention's main elements and gives some background on its evolution, on the phenomenon of international waste trade itself and on other related regulatory initiatives.

Although the provisions of the treaty lack stringency on some central issues, they may in their overall substance be viewed as a constructive step towards controlling environmental dangers which the disposal or treatment of hazardous waste generates in particular in developing countries.

\section{Environmental Problems as Topics of Foreign Policy: Mexico - USA}

\section{By Günther Maihold}

Due to the impact of the United Nations Conference on the Human Environment at Stockholm in 1972, a tendency evolved in international environmental policy to favour international organizations as main actors in the political efforts to advance in the regulation of environmental concems on a world-wide scale. As these organizations were unable to perform an effective role in this area, a shift in environmental policy has been proposed that could be able to provide new impetus for international environmental law and a solution for the consequences of international interdependence. 